\title{
FOREIGN INVESTMENT CONTROLS: POLICY AND RESPONSE*
}

\author{
ANThony M. Solomon†
}

I

When the rules governing the international payments system were worked out at Bretton Woods in 1944 , their object was to free international trade from restraints. Trade, the expansion and balanced growth of trade, was the route to international prosperity. Countries were to avoid resort to restrictions on trade and current payments. But they were quite free to control capital movements. Indeed Keynes suggested at the time "that control of capital movements, both inward and outward, should be a permanent feature of the post-war system." 1 This attitude toward capital movements was, of course, strongly influenced by the disorderly experience of the inter-war years when capital movements in the form of hot money flows were a disruptive and destabilizing force. Capital controls did not, in fact, become a permanent feature of the arrangements, but what is interesting is that in the Bretton Woods system, freedom of capital movement was not thought necessary to national and international prosperity.

In the post-war period, international investment, especially direct investment, has grown at a phenomenal clip, faster than world trade, which itself has been growing faster than world income. A few numbers give the picture. The book value of U.S. direct investments worldwide increased almost fivefold from about \$12 billion in I950 to perhaps $\$ 60$ billion now. U.S. direct investment in Europe increased more than tenfold. The annual output of these overseas enterprises is about \$120 billion. This compares with U.S. export sales of some $\$ 30$ billion. American foreign investment has accounted for the largest flows, but businesses in other countries have also made appreciable foreign investments. Much international trade is now trade between parent company and affiliate, and increasingly foreign investment is a substitute for foreign trade.

One can speculate whether, were the Bretton Woods Conference held today, the rules would be written differently, i.e., to protect the free flow of capital as well as of current items.

It was not from any lack of appreciation of the contribution to the U.S. balance of payments and to the growth of the world economy made by foreign direct investments that the voluntary guidelines and the mandatory restraints were adopted. Nor

\footnotetext{
* This paper was delivered at the Conference on Transatlantic Direct Investment and the Balance of Payments, at Georgetown University Law Center, Sept. 25, 1968.

† Assistant Secretary of State for Economic Affairs, June 1965 to January 1969 .

$I_{2}$ Proceedings and Documents of United Nations Monetary and Financial Conperence 1566 (Bretton Woods, N.H., July I-22, I944).
} 
were those controls adopted because the Bretton Woods system sanctioned them for countries in balance of payments difficulties. It was because our options were limited, and we tried to choose the least-cost route.

A country in deficit in its balance of payments can ride out the deficit by financing it. But our deficit had persisted for years. Our reserves are finite and the willingness of countries to hold dollars is not unlimited, as the crises of confidence in the past year made abundantly clear. We could not continue along this route indefinitely.

Alternatively, a country in deficit can deflate its economy to reduce demand for foreign goods and services. But a large relatively self-contained economy like ours would require a massive deflation of its national income to affect its external position significantly. The economic and social costs at home and the injury to the world economy would be unacceptably high.

(Let me note parenthetically, so there will be no mistake, that I am not talking about the disinflation which we need, and for which the income surtax was enacted, in order to reduce excess demand and check rising prices. Price stability is a domestic policy goal, quite apart from balance of payments considerations. Deflation, the deliberate contraction of demand well below the economy's capacity to produce in order to achieve balance of payment equilibrium, is quite another thing.)

Lastly, a country in deficit can act on the external transactions directly. For years we tried the positive route of increasing our receipts rather than curbing our payments. We encouraged exports abroad, tourism and foreign investment here. These programs are being strengthened and are having good effects. And we tied aid and tried to offset military expenditures abroad to reduce the drain on the balance of payments. But it became necessary to curb our payments as well. To restrict imports would have done great damage to our international economic relations and invited retaliation and a downward spiral in international trade-all the more so if we contemplated trade restrictions while permitting capital to flow out unchecked. Restrictions on travel expenditures proved politically unacceptable and are in any case difficult to apply equitably. Nor could we significantly curtail government expenditures abroad that are necesary to our political and military security. Temporary curbs on private lending and direct investment were judged to be the least-cost route.

Two points about the direct investment controls need emphasis. The program is directed at new outflows of funds and reinvested earnings; it does not aim to curb plant and equipment expenditures as such. It is the source of financing not the investing that is at issue. Funds raised abroad are specifically exempt from the controls. Secondly, the impact of the controls is on the surplus countries of Western Europe, with a minimum impact on other countries. The reason is simply that while the countries of Western Europe need our technology and management skills, they do not need our savings as such to supplement European savings. These capital transfers were not used by Europe to purchase bricks and mortar from abroad, to supplement domestic output with foreign goods and services. Rather, these savings were 
simply held and stockpiled in Europe as liquid dollar assets in private and central bank accounts or converted into gold from U.S. reserves.

Some investors have challenged the effectiveness of the direct investment restraints even as a temporary measure to improve the balance of payments. They see the restraints as self-defeating even in the short run and seriously damaging to the balance of payments in the longer run. They said exports would fall off initially-some twenty-five per cent of total U.S. exports are estimated to be to affiliates-and would surely fall off in the longer run as others invested abroad and displaced U.S. exports to these markets. They said earnings would fall off, not only from new investments foregone but also from investments previously made, because affiliates would not be able to maintain their competitive position abroad. And earnings from foreign direct investments have been one of the strongest positive elements in the U.S. balance of payments.

Whatever merit these points may have-and one can dispute them-they have in the event proved largely irrelevant. All indications are that direct investment plans for plant and equipment expenditures have not been thwarted because U.S. investors have been able to raise funds abroad in sufficient amounts to continue their investments according to plan.

Foreign plant and equipment outlays of U.S. companies are financed out of many sources. In I967 some fifty per cent of the outlays were financed by capital outflow and retained earnings, a modest amount by long-term borrowing abroad, and the balance from depreciation allowances and short-term borrowing abroad. This practice has continued, but the significant change has been the sharp increase in long-term borrowing abroad. In response to the direct investment program, U.S. affiliates and subsidiaries borrowed about $\$ 1.3$ billion in the Eurobond market during the first half of I 968 alone, an amount more than double the volume of such borrowing in all of 1967 and four times the volume of Eurobond flotations by U.S. companies in all of 1965 .

We expect that for 1968 U.S. companies will have raised or established credit facilities abroad of between $\$ 4.5$ to $\$ 5$ billion, perhaps forty per cent from the longterm bond market and the balance from overseas branches of U.S. banks, foreign banks, insurance companies, and other foreign financial institutions.

In short, the investment program appears to be working as we had hoped it would, not by checking desirable expansion but by shifting the source of financing to countries with strong balance of payments and reserve positions, mainly European countries. The Eurobond market has significantly supplemented the New York market as a source of long-term financing not only for U.S. investors but for European, Japanese, and other investors as well. There is no evidence that this market is suffering from indigestion. Indeed, U.S. convertible issues have been oversubscribed. Nor has the cost of borrowing been excessive. Interest rates in the Eurobond market have been relatively low, certainly less expensive than in most 
European domestic securities markets and not much more costly than in the New York market. The history of the past five years would indicate that the scope of the Euro-currency market for providing both short and long-term funds is extraordinary and growing wider, faster, and larger. It has widened sources of capital available to borrowers of all nationalities and broadened the array of investment opportunities for foreign lenders.

Moreover, there is no evidence that the beneficial effects on the U.S. balance of payments have been offset, as some had feared, by a shift by foreigners in their investment portfolios, out of U.S. equities into higher yielding convertible issues offered abroad. On the contrary, net foreign purchases of U.S. equities hit a new peak in 1968. It is true, of course, that interest costs on new borrowings abroad are a current charge on the balance of payments. But if investment were financed by outflows, rather than by borrowing, dollar holdings of foreigners would increase thereby, and interest would have to be paid on these increased dollar holdings.

In noting that some fears have not materalized and that some important side benefits have been realized, I am not suggesting that the mandatory program is a good thing in itself in any absolute sense. I repeat the point I made earlier. In coping with our balance of payments deficit, we have a range of options, and it is desirable, in selecting among these, to take the least-cost route. The mandatory program has put real burdens on U.S. international companies; it is a temporary program, to be eliminated as soon as world payments conditions permit.

\section{II}

Let me turn now to other aspects-other than the balance of payments-of this subject of transatlantic investment.

The economic case for open transatlantic investment is the classical case-that is, world output will be greater if capital and management skills go where they can be employed most efficiently, from areas of low return to areas of high return. Not all transatlantic direct investment moves for reasons of economic efficiency, of course. Some direct investment may be made because it is fashionable; everybody's doing it. Some investment is made to get behind tariff walls or to enjoy tax advantages. These are locational advantages that would disappear were trade barriers lowered or tax policy made more neutral. But much transatlantic direct investment is certainly made either because costs are lower, or management skills are scarcer, or the market can be better served when the investor is close to it and able to adapt to local tastes and specifications.

The bloodless, dry-as-dust language of people who talk of efficient allocation of world resources gives no inkling, however, of the fears, tensions, and high drama that this subject of foreign investment generates. "Industrial helotry," "technological colonialism," "soulless instruments of American managerial imperialism"-these more 
colorful phrases give us some flavor of and some insight into the emotions that surround the subject of foreign direct investment.

I would like to discuss the fears and tensions that transatlantic investment stimulates because they are a fact of transatlantic life. But let me say at the outset that I find it ironic that all the concern, all the furor, is in the receiving countries, the countries that receive real, direct, immediate benefits from the investment. The costs to the home country, such as the costs in time before returns are realized, the possible displacement of exports, the possible effects on home employment, are not noted, or if noted, then in muted tones.

What are some of the fears and tensions that foreign direct investment generates in the host country? There is first the fear of foreign control of important sectors of the economy. Managerial control, decisions affecting the affiliate-whether it will expand or contract, what it will make, what markets it will service, and so forthare made not by the local national who may be in charge of local operations but by the foreign parent domiciled in another country. The fact that the key decisions made by the parent are probably no different from the decisions that a large and broadly-based national corporation would make in the circumstances does not matter. The point was made in a report on U.S.-Canadian economic relations that a profit maximising firm will behave in precisely the same way no matter what the nationality of its management. ${ }^{2}$

This nationalist uneasiness is reinforced and given point when the government of the home country-where the head office is located-extends its control through the parent to the affiliate overseas to enforce purely home country policy. As the Economist put it recently: "[W]hen the American Government gets in a jam, they [the international companies] are apt, suddenly, to become American. They must not leave their dollars lying around Europe; they must not sell computers to Poland and so on."

This problem of extraterritoriality exists, of course. But is its actual impact extensive enough to constitute the heart of the fear of foreign control? Or is it a telling point to justify an emotional and irrational attitude that would persist in any case?

If, for example, the parent were domiciled in Ruritania-or, better yet, on the moon, a place without any history, tradition, or national style-and if the Government of Ruritania faithfully abstained from any extraterritorial intrusions into the activities of affiliates in other countries, would this assuage fear of foreign control? I think not, if the parent were itself a powerful, rich, multinational corporation. Would the fear be assuaged if the equity of this powerful, rich, multinational corporation were widely distributed through international stock ownership? I doubt it. Would the fear be assuaged if the top management in Ruritania were multinational

\footnotetext{
${ }^{2}$ Brecher \& Reisman, Canada-United States Relations, Royaz Commission on Canada's Economic Prospects (I957).

${ }^{3}$ The Economist, July 13, 1968, at 65.
} 
in character? Perhaps. What would remain would be distaste for foreign control, much like the distaste for absentee landlords. The argument goes that the affiliate is loyal to a foreign sovereign, or it is loyal to an international entity. In any case, its loyalty isn't purely local, and there is the rub.

It seems to me that the fear of foreign control is not rational in the transatlantic world. In the nineteenth century world of banana republics, of small countries and weak governments, the fear of foreign domination had a rational basis. But it has no meaning in the Atlantic community today. It is a hangover.

This fear is played on for both destructive and constructive purposes. It is played on fortissimo by Servan-Schreiber ${ }^{4}$ because he wants to use this fear to hasten the unification of Western Europe. It is a useful psychological weapon for this purpose. It is also played on destructively by shortsighted men who are basically narrow nationalists.

Another fear is summed up in the phrase "technological gap." Developing countries accept the technological gap as a fact of life, but advanced industrialized countries feel uneasy and insecure if they are dependent on outside sources for the technology essential to their national objectives. Foreign direct investment brings new methods, trains local personnel in advanced techniques, and enables the host country to exploit the new technology for commercial advantage. The foreign enterprise is welcome for these reasons. But, unless the host country is itself an innovator on a wide front, the insecurity persists. The host country is forever breathlessly catching up, absorbing the results of research and development done elsewhere. Compounding this uneasiness and allied to it is the "brain drain" fear, the fear that the United States, with its lead in advanced sectors, its large research centers, heavy corporate expenditures in research and development, and its wide governmental support, will prove an irresistible magnet for European scientists and engineers. Europe will lose its capability for independent research, even as it grows richer by using the fruits of American research. National power and prestige are at issue here. Intellectual investment determines national independence in the long run, says the French Ministry of Industry in one of its reports. ${ }^{5}$ Europe will import inventions and export brains, says Servan-Schreiber. ${ }^{\mathfrak{B}}$

The Japanese handled the technological gap problem in their own way. They imported virtually all their modern technology under licensing agreements with the West but kept their economy closed to foreign investors. They adapted and improved the borrowed technology, applied it, expanded volume in the protected home market to reduce unit costs, and then exported. Now they are relying on their own basic research not only for adaptations but also increasingly for important innovations. Japan is only now beginning to liberalize its direct investment restraints and is doing

\footnotetext{
- See J. Servan-Schreiber, The American Challenge (1968).

'United States Investment in France: The Case of the Hesitant Host, Conference Board Recond of JANUARY I957, at 3 I ( $I 967)$.

${ }^{\circ}$ See Servan-Schreiber, supra note 4 , at I04.
} 
so very slowly except for industries that have little potential-wooden clogs is the example one Western reporter thought typical ${ }^{7}$-or industries in which they have a strong competitive edge.

The Japanese took this nationalist approach, bending the rules of the game. The policy worked for them. The Western world permitted it because the Japanese were newcomers. But it has not been without its costs to Japan. And it is certainly not a policy to be recommended to the Western world. The answer for Europe is not the Japanese path of restrictions on foreign investment. The answer is surely the integration of Europe, providing European industrialists with larger, surer, more unified markets and incentives for competitive innovation.

Foreign investment sets up other tensions and anxieties. The fear of Americanization of European society is one. The American corporation has its own style and methods of operation that have a deep sociological effect on the United States. I need only note to illustrate that the hiring and firing practices of American business are alien, indeed, regarded as immoral, in many parts of the world.

The fact that the foreign investor has outside sources of funds that enable it to thwart restrictive monetary policies in the host country and perhaps make it less amenable to government persuasion is yet another source of friction. I doubt that this materializes on any significant scale.

But, as I mentioned earlier, not all the problems are in the receiving country. There are problems for the home government as well, quite apart from the effects on its balance of payments. The ability of the American investor to evade U.S. taxation through tax havens abroad and intracorporate pricing, and to frustrate regulations governing fraud and disclosure, antitrust policy, and important foreign policy objectives affecting trading with the enemy are by-products of the increasing internationalization of American business.

\section{III}

Where do we go from here? Of course there are problems in a world of larger and larger business units and increasing economic interdependence, but the gains far outweigh the costs. The problems are not intractable; they are manageable. The governments of the Atlantic community can and do consult, cooperate, and make modifications in their common interest.

It has been suggested that we go further and by international agreement establish rules of the game to reconcile national interests and make international investment subject to conventions of behavior both by host and home governments governing the proper jurisdiction of each and governing the behavior of the firms themselves.

The primary reason, in my view, that there has not yet been concrete movement by governments in this direction is that it is not yet clear to governments and to

\footnotetext{
${ }^{7}$ Norman Macrae, in The Economist, May 27, 1967, at xxvii.
} 
experts what the content of such an international agreement might be. Businessmen have wanted an international code for years, but their traditional interest has been primarily to protect themselves from expropriation. But this is not a problem in the Atlantic community. Take antitrust policy. Are the governments of the Atlantic community ready to agree on this? The problems of fraud and disclosure, pollution, taxation, and extraterritorality, although abrasive, have not yet proven so difficult that there is felt to be a compelling need for a comprehensive international agreement.

We are told that in the years ahead some 300 or 500 major international corporations will own seventy-five per cent of the fixed industrial assets outside the public sector in the non-Communist world. Each of them will be subject to conflicting national jurisdictions and able to some extent to evade the jurisdiction of any. This raises important questions of public versus private power. Will the critical decisions be made in the board rooms or in the parliaments? These problems of conflicting jurisdictions and of regulation in the public interest will, it seems to me, lead inevitably to international agreement and perhaps to international machinery for administration. What the specific substance of such an agreement might be will be worked out in the years ahead in the light of developments, but the purpose is clear: to enable world-minded corporations to serve the world's interest as properly regulated citizens of the world. 